\title{
Katılım Bankalarının Finansal Performans Analizi
}

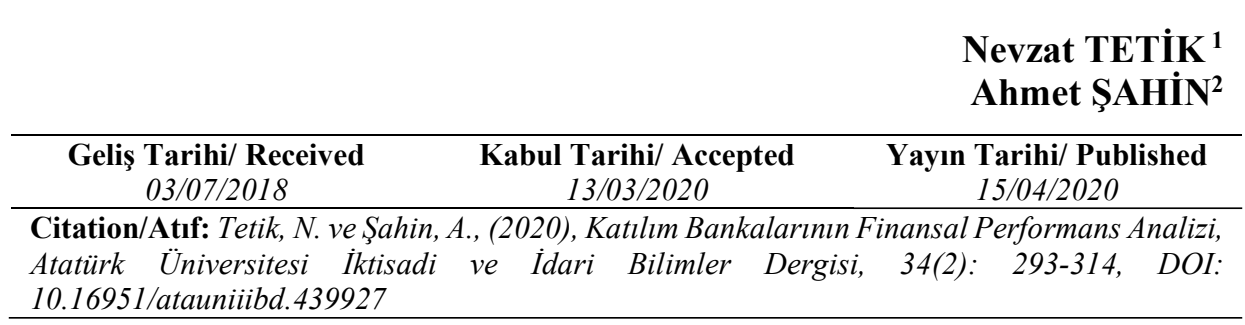

Öz: Türkiye'deki ismi ile katılım bankacılığı, İslami finans ilkeleri çerçevesinde faizsiz bankacılık faaliyetlerini gerçekleştiren banka türüdür. Geleneksel bankacılık hizmetlerinden temelde ayrımı faizsiz işlemler olan katılım bankacılığı, 2019 yılı sonu itibariyle Türkiye'de altı katılım bankası ile faaliyet göstermektedir. Katılım bankaları ülkemizde son yıllarda kalkınma planları çerçevesinde finans sektörünün ve bankacılık sisteminin hızla büyüyen ve gelişen bir parçası haline gelmiştir. Söz konusu bankalar mevcut yapı ve işleyişleri ile ülke ekonomisine önemli ölçüde katma değer sağlamaktadır. Bu çalışmada Türkiye'de 2011-2019 yıllarında faaliyet gösteren yedi katılım bankasının finansal performansları TOPSIS yöntemi ile analiz edilerek değerlendirmelerde bulunulmuştur. Bu tür analizler katılım bankalarının kriz, iflas, likidite sıkıntısı gibi muhtemel gelişmelere önceden hazırlıklı olmasına yardımcı olmaktadır. Katılım bankalarının finans sektörü içerisindeki rolünün arzu edilen seviyeye çıkması için güçlü bir finansal yapıya sahip olmaları zorunludur.

Anahtar Kelimeler: Katılım Bankaları, Faizsiz Bankacılık, İslami Finans, Finansal Performans, TOPSIS Yöntemi

The Financial Performance Analysis of the Participation Banks

Abstract: The type of banking, which is called participation banking in Turkey, implements interest-free banking in the framework of Islamic finance principles. Participation banking, whose basic difference from traditional banking services is interest-free transactions, has been operating with six participation banks in Turkey by the end of 2019. Participation banks have become a rapidly growing and developing part of the financial sector and the banking system within the framework of development plans in recent years in our country. The relevant banks provide significant added value to the country's economy with current structure and functioning. In this study, the financial performance of seven participation banks operating in Turkey between 20112019 have been analyzed by TOPSIS method and evaluations were made. Such analyzes enable the participation banks to be well prepared for possible developments such as crisis, bankruptcy and liquidity difficulties. For the role of participation banks in the financial sector to reach the desired level, it is imperative that they have a strong financial structure.

Keywords: Participation Banks, Interest-Free Banking, Islamic Finance, Financial Performance, TOPSIS Method

${ }^{1}$ Doç. Dr., İnönü Üniversitesi, İktisadi ve İdari Bilimler Fakültesi, İşletme Bölümü, https://orcid.org/0000-0002-3152-8217

${ }^{2}$ Öğr. Görevlisi, Adıyaman Üniversitesi, Besni Meslek Yüksekokulu, Finans Bankacılık ve Sigortac1l1k Bölümü, https://orcid.org/0000-0003-2145-8961 


\section{Katılım Bankalarının Finansal Performans Analizi}

\section{EXTENDED SUMMARY}

Background: The basic discrimination from conventional banking services is interest-free transactions. In recent years, Islamic finance, which has begun addressing the large masses, is a sector that is located in also other countries besides Islamic countries within a growing trend. The participation banks, which have an important place in the Islamic finance sector but also because of different reasons could not take a proper place itself throughout the economic cycle, ensure an alternative to traditional banks in a way diversifying the traditional banking sector as they integrated the passive funds, which could not be included in the economy, into the system within the principles of interestfree banking, they provided an alternative to traditional banks, thus diversifying the traditional banking sector. Besides, the participation banks make important contributions to the economy, such as improving the income distribution, providing resources to the real sector, reducing the grey-economy and increasing employment opportunities.

Purpose and Method: The aim of this study is to analyze the performance of participation banks operating in the Turkish banking sector between 20112019 using the TOPSIS method.

Findings: As a result of the analysis, "Türkiye Finans Katılım Bankası" is the bank with the highest financial performance among the participation banks. "Albaraka Türk Katılım Bankası" is located at the second rank and "Kuveyt Türk Kat1lım Bankası" is located at the third rank. Therefore, due to transferred to the saving deposit insurance fund in 2014 and abrogating official authorization in 2015, "Bank Asya" remains behind these three participation banks in terms of financial performance points. We observe that "Ziraat Katılım Bankası", "Vakıf Kat1lım Bankası"'and "Emlak Katılım Bankası" could not get high financial performance scores in their first years because they are newly constituted banks, but they improved in 2018 and 2019.

Conclusions: In Turkey, the participation banks raise their share in the banking system each year regularly and continue their activities with a steadily increasing growth rate. Notwithstanding, the participation banks' role in the banking sector increasing day by day, does not appear to be at the desired levels yet. The participation banks are required to have a strong financial structure in order to reach the desired levels. It is also important the amount and development of funds collected, in addition, to have a sufficient equity structure. While the participation banks increased their equities by $89.36 \%$ in the last three years, their funds also increased by $159.65 \%$. In this period, respectively there were $64 \%$ and $76.51 \%$ increases in the banking sector. These results show that the participation banks have eliminated the problems in the 2014-2015 period and continue their development trends. Beyond doubt, the participation banks are required to have a much stronger financial structure in order to reach the target set as a $15 \%$ share in the banking sector in 2025. The participation banks, which have a strong financial structure and could stand firmly against the risks that may arise and 
possible crises, would contribute to the development of the country's economy while maintaining their own assets in a healthy way.

From this point of view, it could be expected that having sufficient equity would increase the participation banks' share in the sector to the extent that the trust and reputation among the public would be realized with similar sensitivity in interest-free banking transactions in the future periods. In recent years, we could say that the public participation banks started to operate in the sector and the funders felt under the state guarantee was effective in the rapid increase of participation banks in total funds since 2016. On the other hand, the sector is considered far from supporting the desired growth in the long run, considering the collected funds and increase percentages. It is essential to increase the number of financial products which are a limited number of assets and liabilities in the balance sheets in order to grow and develop the participation banking in Turkey on a global scale in line with desired targets. In the context of Istanbul being a financial center, new financial instruments that could appeal to the global market should be created urgently or, although not used in Turkey, the adaptation of new financial products from experienced countries such as Malaysia and Indonesia to Turkey.

\section{Giriş}

İslamiyet'te faizin yasaklanması ve geleneksel finans piyasalarında faiz temelli işlemlerin yapılıyor olması, faiz hassasiyeti olan kişilerin mevcut finansal varlıklarını finansal sistem içerisinde değerlendirememesine neden olmuştur. Ayrıca günümüz koşullarında İslam ülkeleri arasında sermaye hareketlerini canlandıracak ve bu ülkeler arasında iş birliğini gerçekleştirecek alternatif kurumlara ihtiyaç duyulmuştur. Bu sorun ve ihtiyaçları gidermek amacıyla ortaya çıkan İslami finans anlayışı, modern finans anlayışına alternatif olarak kabul edilmiştir İslami finans, yapılan her türlü finansal işlemde İslami kuralları göz önünde bulundurmayı gerekli kılan bir finans sistemidir. Türkiye'deki ismi ile katılım bankacılığı da İslami finans kuralları içerisinde faizsiz bankacılık işlemlerini yerine getiren bir yapıyı ifade etmektedir (Kınalı, 2012: 61-64; Pehlivan, 2016: 299). Bu finansal yapı içerisinde faaliyet gösteren bankaların yerine getirdikleri işlemler açısından geleneksel bankacılıktan en temel farkı; tasarrufları toplama ve yatırıma aktarma işlevlerinin faizsizlik prensibine göre gerçekleştirilmesidir (Yanpar, 2014: 125).

Türkiye'de İslami bankacılık faaliyetleri, 16.12.1983 tarihli Bakanlar Kurulu Kararı neticesinde o günkü resmi adları olan "Özel Finans Kurumları" ile gündeme gelmiştir. Bu karar sonucunda Albaraka Türk Özel Finans Kurumu 21.01.1985 tarihi itibariyle faaliyet izni alarak Türkiye'de kurulan ilk özel finans kurumu olmuştur (Atar, 2017: 1052). 2005 y1lında özel finans kurumlarının katılım bankası adını alması ve Bankacılık Kanunu'na tabi tutulmaları faizsiz bankacılığın ülkemizdeki gelişimini desteklemiştir. 2010 yılında faaliyette olan katılım bankalarının toplam aktif büyüklüğü 43,3 milyar TL iken bu rakam 2019 


\section{Katılım Bankalarının Finansal Performans Analizi}

yılında 284,4 milyar TL'ye yükselmiştir. Bir başka ifadeyle katılım bankaları son dokuz yıllık sürede $\% 556,81$ büyümüştür (www.tkkb.org.tr).

Bankacıllk sektöründe giderek daha büyük bir paya sahip olmaya başlayan katılım bankaları, faaliyetlerinde geleneksel bankacılık sisteminde kullanılan tekniklerden de yararlanarak, farklı bir bakış açısıyla kullanılmayan fonları ekonomiye kazandırmaktadır. Ayrıca katılım bankalarının ekonomik kriz dönemlerinde ticari bankalara oranla krizden daha az etkilendikleri de göz önünde bulundurulmaktadır (Çobankaya, 2014: 56). Gösterdikleri hızlı gelişim ile birlikte finans sektörü ve bankacılık sektörü açısından önemli bir düzeye yükselen katılım bankalarının farklı ülkelerdeki konumları göz önünde bulundurulduğunda, ülkemizde henüz arzu edilen seviyede olduğu söylenemez (Nakiboğlu ve Levent, 2018: 182). Kalkınma Bakanlığının 2018-2020 orta vadeli programı çerçevesinde, faizsiz finansman yöntemlerine özel bir önem verilmekte ve bu yöntemler desteklenerek teşvik edilmektedir (T.C. Kalkınma Bakanlığı, 2017). Aynı şekilde Türkiye'nin 2023 hedeflerine ulaşması için hazırlanan On Birinci Kalkınma Planında da finans sistemine derinlik kazandırmak amacıyla katılım bankacılığına ayrı bir önem verildiği görülmektedir (T.C. Strateji ve Bütçe Başkanlı̆̆ı, 2019). Ayrıca katılım bankaları da 2025 yılında bankacılık sektöründen aldıkları payı \%15 seviyesine çıkarmayı kendilerine hedef olarak belirlemişlerdir (Türkiye Katılım Bankaları Birliği [TKBB], 2015: 3). Tüm bu belirlenen hedefler ve katılım bankacılığına verilen önem ve destekler sonucu katılım bankacılığının önümüzdeki yıllarda daha da gelişeceği ve bankacılık sektörü içerisinde daha önemli bir konuma geleceği öngörülmektedir.

Bu çalışmada katılım bankacılığı hakkında genel hatlarıyla bilgi verilerek, katılım bankacılı̆̆ının ülke ekonomisi içerisindeki yeri ve önemi finansal veriler çerçevesinde irdelenecektir. Bununla birlikte çalışmanın ana temasını oluşturan katılım bankalarının finansal performansları, TOPSIS yöntemi kullanılarak analiz edilerek değerlendirmeler yapılacaktır.

\section{Katılım Bankacılığı Kavramı ve Temel Fonksiyonları}

İslam dininin kutsal kitabı olan Kur'an-1 Kerim'de ve sünnette faizin açı bir şekilde yasaklanması ve alışverişin helal kılınması, İslam ülkelerinde alternatif bir bankacılık sistemi arayışını zorunlu kılmıştır (Baykara, 2012: 17). $\mathrm{Bu}$ düşünce temelinde ortaya çıkan katılım bankacılığı, mali sektörde faizsizlik prensiplerine göre hareket eden, bu prensiplere uygun olarak her türlü bankacılık faaliyetlerini yerine getiren kuruluşlardır. Bu kuruluşlara farklı ülke ve kültürlerde "İslami banka", "kâr-zarar ortaklığı bankası" ya da "faizsiz banka" şeklinde isimler verilmekle birlikte hepsinin benimsediği ilkeler aynıdır. Söz konusu bankalar tasarrufları toplamak ve bu tasarrufları yatırıma yönlendirmek işlevini geleneksel bankalardan farklı şekillerde yerine getirirler (Pehlivan, 2016: 298). Katılım bankaları, topladıkları fonları kişi ya da kuruluşlara kullandırarak, ülke ekonomisine önemli katkı sağlamaktadırlar. Geleneksel bankacılıkta da bu işlem yerine getirilmektedir ancak burada, önceden belirlenmiş bir faiz oranı 
karşıllığında fon fazlası olanlardan toplanan mevduatlar, bankanın belirlediği faiz oranı üzerinden fon ihtiyacı olanlara kredi şeklinde kullandırılmaktadır. Katılım bankacıllı̆ında ise, önceden belirlenmiş bir faiz oranı ile fonların toplanması yerine, ticaret sonucunda elde edilecek dönem sonundaki kâr veya zarara fon sahiplerinin katılımının sağlanması amaçlanmaktadır (Özkan, 2012: 4).

Genel olarak katılım bankaları, konvansiyonel bankalar gibi fon kullandırma ve fon toplama faaliyetleri neticesinde önceden belirlenmiş bir oranda faiz ödemesinde bulunmayı veya faiz tahsil etmeyi taahhüt etmezler. Yatırıma katılmayı ve müşterilerin kâr veya zararına ortak olmayı amaçlamaktadırlar. Katılım bankaları faizsiz işlem yapma prensibi doğrultusunda, konvansiyonel bankaların finansal piyasalarda yatırım yaptığı faiz üzerinden işleme konu olan enstrümanları kullanmadığı için genellikle yatırımları reel sektöre yönelik olmaktadır (Gökçen ve Gönen, 2017: 62).

\section{Türkiye'de Katılım Bankacılığının Gelişim Süreci}

Türkiye'nin katılım bankacılığı ile tanışması, 1980'li yıllarda kapalı ekonomiden serbest piyasa ekonomisine geçişin yaşandığı dönemde uluslararası piyasalara uyum sağlamak için yapılan çalışmalar sonucunda gerçekleşmiştir. Ayrıca, Türkiye olarak 1975 yılında İslam Kalkınma Bankası'nın kurucu üyelerinden biri olunması ve 1984 yılında da bu kuruluşun en büyük ortaklarından biri haline gelinmesi ülkemizdeki faizsiz bankacılığın gelişimi açısından önemli bir adım olmuştur (Çobankaya, 2014: 38).

Türkiye'de katılım bankacılığının temeli, 16.12.1983 tarihli Bakanlar Kurulu Kararnamesi ile atılmıştır. Bu kararname ile Türkiye'de "Özel Finans Kurumu (ÖFK)" adı altında faizsiz işlem yapma prensibine sahip olan kuruluşların kurulmasına imkân tanınmıştır. Bu sayede faiz hassasiyetine sahip olan ve parasını ticari bankalarda değerlendirmek istemeyen "yeşil sermaye" adı ile anılan kesimin "yastık altında" tuttuğu parasını ekonomiye kazandırmak amaçlanmıştır. Bu tarihten sonra ilki "Albaraka Türk Özel Finans Kurumu" olmak üzere toplam 6 tane özel finans kurumu kurulmuştur. Özel finans kurumlarının isimleri ve kuruluş tarihleri Tablo 1'de gösterilmiştir.

Tablo 1. Özel Finans Kurumlarının Kuruluş Yılları

\begin{tabular}{|lc|}
\hline Katılım Bankaları & Kuruluş Yılları \\
\hline Al Baraka Türk Özel Finans Kurumu A.Ş. & 1984 \\
\hline Faysal Finans Kurumu A.Ş. & 1984 \\
\hline Kuveyt Türk Evkaf Finans Kurumu A.Ş. & 1988 \\
\hline Anadolu Finans Kurumu A.Ş. & 1991 \\
\hline İhlas Finans Kurumu A.Ş. & 1995 \\
\hline Asya Finans Kurumu A.Ş. & 1996 \\
\hline
\end{tabular}

1999 y1lında, 4491 sayılı “4389 sayılı Bankalar Kanunu’nda Değişiklik Yapılmasına İlişkin Kanun” ile ÖFK'ların Bankalar Kanunu kapsamına 
alınmasına karar verilmiştir. Bu kanun ile ÖFK'lar 4389 sayılı Bankalar Kanunu'nun bazı maddeleri dışındaki diğer maddelerine tabi olmuş ve Bankacılık Düzenleme ve Denetleme Kurumu'nun (BDDK) kapsamına alınmışlardır.

ÖFK'lar arasında yer alan "İhlas Finans Kurumu" 2000 yılının son çeyreğinde ortaya çıkan ve özellikle bankacılık ve finans sektörünü derinden yaralayan krizden olumsuz yönde etkilenmiştir. Bunun sonucu olarak İhlas Finans Kurumu 2001 yılında, BDDK'nın 10.02.2001 tarih ve 171 sayılı kararı ile faaliyet izni durdurularak Tasarruf Mevduatı Sigorta Fonu'na (TMSF) devredilmiştir (www.ifk.com.tr).

19.10.2005 tarihinde kabul edilen ve 01.11.2005 tarihinde yürürlüğe giren 5411 sayılı Bankacılık Kanunu ile Özel Finans Kurumları'nın isimleri "Katılım Bankası" olarak değiştirilmiştir. Ayrıca ÖFK'ların bağlı oldukları Özel Finans Kurumları Birliği’nin ismi de "Türkiye Katılım Bankaları Birliği” olarak değiştirilmiştir. Bu değişikliklerden sonra faaliyet gösteren ÖFK'lardan ismini 2001 yılında Family Finans Kurumu olarak değiştirmiş olan Faysal Finans Kurumu ile Anadolu Finans Kurumu 30.12.2005 tarihinde birleşme yoluna gitmişler ve Türkiye Finans Katılım Bankası adını almışlardır. Türkiye Finans dışında 2005 yılsonu itibariyle Türkiye'de faaliyette olan katılım bankası sayısı Albaraka Türk Katılım Bankası, Kuveyt Türk Katılım Bankası ve Asya Finans Katılım Bankası (Bank Asya) olmak üzere 4 adettir.

15.10.2014 tarihinde Ziraat Katılım Bankası'nın ve 25.06.2015 tarihinde ise Vakıf Katılım Bankası'nın kurulması ile faaliyet gösteren katılım bankası sayıs1 6'ya yükselmiştir. BDDK 29.05.2015 tarihinde, Bank Asya'nın TMSF'ye devredilmesine ve 22.07.2016 tarihinde ise faaliyet izninin kaldırılmasına karar vermiştir. Bu karar ile beşe düşen katılım bankası sayısı, 2019 yılında kamu sermayeli Emlak Katılım Bankası'nın faaliyete başlaması ile birlikte tekrar altıya yükselmiştir.

\section{Katılım Bankalarının Türkiye Ekonomisi İçindeki Yeri ve Önemi}

Katılım bankalarının Türkiye ekonomisi içindeki yerini belirleyebilmek amacıyla aşağıdaki grafikler oluşturulmuştur. $\mathrm{Bu}$ grafiklerde yer alan veriler Türkiye Bankalar Birliği, Türkiye Katılım Bankaları Birliği ve Bankacılık Düzenleme ve Denetleme Kurumu'nun internet adreslerinde yayınlanan kaynaklardan elde edilmiştir.

Şekil 1 incelendiğinde; katılım bankalarının aktif büyüklüğündeki y1llar itibariyle değişim yüzdesinin, pozitif olmakla birlikte 2014 y1lına kadar sektör ortalamasından daha yüksek gerçekleştiği görülmektedir. 2014 yılında Bank Asya'nın TMSF'ye devredilmesi ile katılım bankaları hem 2014 hem de 2015 yıllarında toplam aktiflerde bankacılık sektöründen daha az büyüme gerçekleştirmişlerdir. Ancak 2016 yılından itibaren büyüme yüzdeleri sektör ortalamasının tekrar üzerine çıkmıştır. Özellikle 2018 ve 2019 yıllarında katılım bankalarının aktif toplamındaki artış oranı, bankacılık sektör ortalamasının çok 
üzerinde gerçekleşmiştir. Bu gelişim katılım bankalarının sektördeki payının artış trendine girdiğini göstermektedir.



Kaynak: Tarafimızdan hazırlanmıștır.

Şekil 1. Katılım Bankaları ile Bankacılık Sektörünün Aktif Büyüklükleri (Büyüme Yüzdesi)

Katılım bankalarının topladığı fonların yani mevduat toplamının yıllar itibariyle değişimi incelendiğinde (Şekil 2), aktif büyüklükteki ile benzer sonuçlar gözlemlenmektedir. Katılım bankalarının mevduat toplamı 2011 y1lında $\% 51,8,2012$ yılında $\% 23,3$ ve 2013 y1lında \%28,6 artış gösterirken bu üç yılda da bankacılık sektöründeki büyümeden daha hızlı bir yükseliş göstermiştir. Ancak 2014 yılındaki Bank Asya olayı sonrası mevduatın bankadan çekilmesi, büyümenin de azalarak \%5,7'ye gerilemesine sebep olmuştur. 2015 y1lında Ziraat Katılım Bankası'nın faaliyetlerine başlayarak mevduat kabul etmesi ile birlikte katılım bankalarının bir önceki yıla göre mevduat tutarları \% 7,7 artış göstermiştir. 2014 ve 2015 y1llarında katılım bankalarının, sektördeki büyümeden daha az büyüdüğü gözden kaçmamaktadır. 2016 yılında Vakıf Katılım Bankası'nın da faaliyete başlaması ile büyüme oranı \%17,9'a, 2017 y1lında \%26,6'ya ve 2018 y1lında ise \%30,3'e yükselmiştir. Bu yıllarda katılım bankalarının büyüme oranlarının tekrar sektör ortalamasının üstüne çıktığı görülmektedir. Son olarak 2019 yılında, faaliyete başlayan Emlak Katılım Bankası'nın da etkisiyle katılım bankalarının topladıkları fon miktarı 2018 yılına göre \%57,4 oranında artış göstererek 216 milyar TL seviyesinde gerçekleşmiştir (www.tkbb.org.tr). 




Kaynak: Tarafımızdan hazırlanmıştır.

Şekil 2. Katılım Bankaları ile Bankacılık Sektörünün Topladı̆̆ı Fonlar (Büyüme Yüzdesi)

Şekil 3 incelendiğinde, katılım bankalarının kullandırılan fonlar bazında, 2014 ve 2015 yılları dışında sektör ortalamasında bir büyümeye sahip olduğu görülmektedir. Bank Asya'nın TMSF'ye devredildiği 2014 yılı ve takip eden 2015 yılında ise katılım bankalarının kullandırdıkları fonların bir önceki yıla göre sırasıyla \%4 ve \%5,5 oranında artış göstermesine rağmen bankacıllk sektör ortalamasının çok gerisinde kaldığı görülmektedir. Ancak, Bank Asya’yı özel durumundan dolayı analiz dişında tuttuğumuzda, faaliyette olan diğer üç katılım bankasının kullandırdıkları fonları 2014 yılında \%31,24 oranında, 2015 yılında ise \%20,96 oranında artırdıkları ve bu oranların bankacılık sektör ortalamasından daha fazla olduğu görülmektedir (www.tkbb.or.tr). Bu sonuç, katılım bankaları açısından yaşanan olumsuz gelişmenin, katılım bankacılığının gelişimini etkilemediğini ve katılım bankalarının bankacılık sektörü içerisinde güçlü bir yapıya sahip olduğunu göstermektedir. Takip eden yıllardaki artış oranları bu sonucu desteklemektedir.

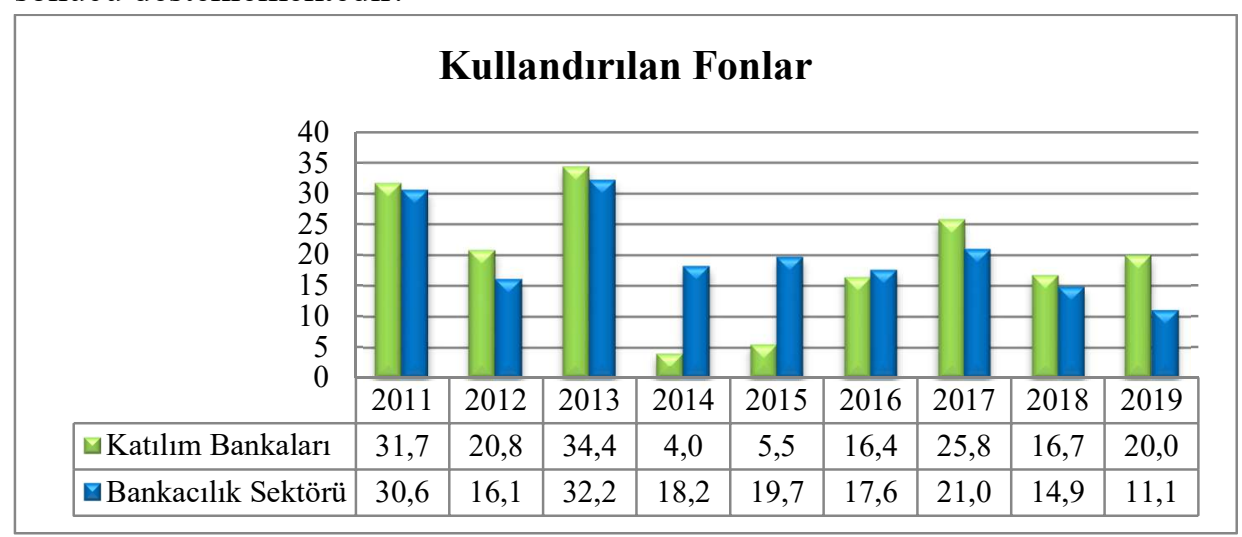

Kaynak: Tarafımızdan hazırlanmıştır.

Şekil 3. Katılım Bankaları ile Bankacılık Sektörünün Kullandırdı̆̆ı Fonlar (Büyüme Yüzdesi) 
Bankacılık sektörü ve katılım bankalarının yıllar itibari ile öz kaynaklarındaki değişim incelendiğinde (Şekil 4), katılım bankalarının öz kaynaklarındaki artış oranın 2011, 2013, 2016, 2018 ve 2019 yıllarında bankacılık sektöründeki artış oranından daha yüksek olduğu; 2012, 2014 ve 2017 yıllarında ise bankacılık sektörünün gerisinde kaldığı görülmektedir. 2015 yılında ise katılım bankalarının öz kaynakları bir önceki yıla göre \%1,5 oranında küçülmüştür. Bunun sebebi 2015 yılında Bank Asya'nın faaliyet izninin BDDK tarafindan kaldırılmasından dolayı bu bankanın katılım bankaları toplamı içerisinde yer almamasıdır. Her ne kadar bu dönemde Ziraat Katılım Bankası faaliyetlerine başlamış olup toplam içerisinde kendine yer bulsa da toplamdan çıkarılan Bank Asya'nın öz kaynak büyüklüğüne ulaşamadığından dolayı, değişim oranı negatif olarak ortaya çıkmaktadır. 2016 yılından itibaren katılım bankalarının öz kaynaklarındaki artış oranı tekrar pozitif seyretmeye başlamıştır. 2019 yılında ise Emlak Katılım Bankası'nın faaliyetlerine başlaması ile birlikte katılım bankalarının öz kaynaklarındaki artış oranı sektör ortalamasının yaklaşık iki katı seviyesinde gerçekleşmiştir.

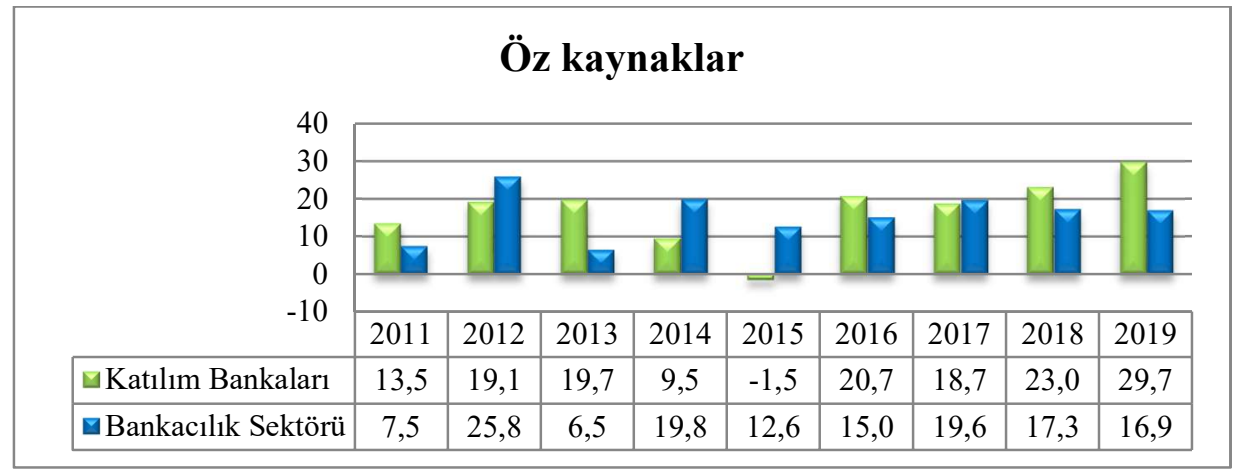

Kaynak: Tarafımızdan hazırlanmıștır.

Şekil 4. Katılım Bankaları ile Bankacılık Sektörünün Öz kaynakları (Büyüme Yüzdesi)

Şekil 5 'te yer alan bankaların yıllar itibariyle kârlılık düzeylerinin değişimi incelendiğinde; 2014 yılı dışında katılım bankalarının kârlılık düzeyindeki değişim oranının pozitif yönlü ve 2012 yılı hariç bankacılık sektör ortalamasından daha yüksek olduğu görülmektedir. 2014 yılında ise; yönetimi TMSF'ye devredilen Bank Asya'nın mali performansındaki özel durumu nedeniyle, katılım bankalarının 2014 yılı kârında küçülme izlenmiştir. Ancak katılım bankacılı̆̆ sektöründe yer alan diğer üç katılım bankasının mali tabloları incelendiğinde, kârlılıktaki büyümenin $(\% 9,9)$ istikrarlı bir şekilde devam ettiği açıça görülmektedir (www.tkbb.org.tr). Diğer yandan, 2014 yılında TMSF'ye devredilen katılım bankasının açıkladığı zarar nedeni ile kârlılık oranlarında keskin düşüş yaşayan katılım bankalarının, 2015 yılında ilgili katılım bankasının faaliyet izninin kaldırılması ve toplamdan çıkarılması ve Ziraat Katılım Bankası'nın faaliyete başlaması ile katılım bankalarının net kârının \%184 oranında arttığı görülmektedir. 2016 yılında ise Vakıf Katılım Bankası'nın 
sisteme dâhil olması ile birlikte katılım bankalarının net kâr tutarı \%170,4 oranında artış göstermiştir. Bu iki yılda da katılım bankalarının net kârındaki artış yüzdeleri bankacılık sektör ortalamasının çok üzerinde gerçekleşmiştir. Emlak Katılım Bankası'nın faaliyete başladığı 2019 yılında ise katılım bankaları kârlarını 2018 yılına göre \%16,3 oranında artırmıştır. Bankacılık sektörünün net kâr durumunda bir önceki yıla göre \%9,4'lük azalmanın yaşandığ 2019 yılında katılım bankalarının faaliyetlerine kârlarını artırarak devam etmeleri, sektör açısından göz önünde bulundurulması gereken bir gelişmedir.

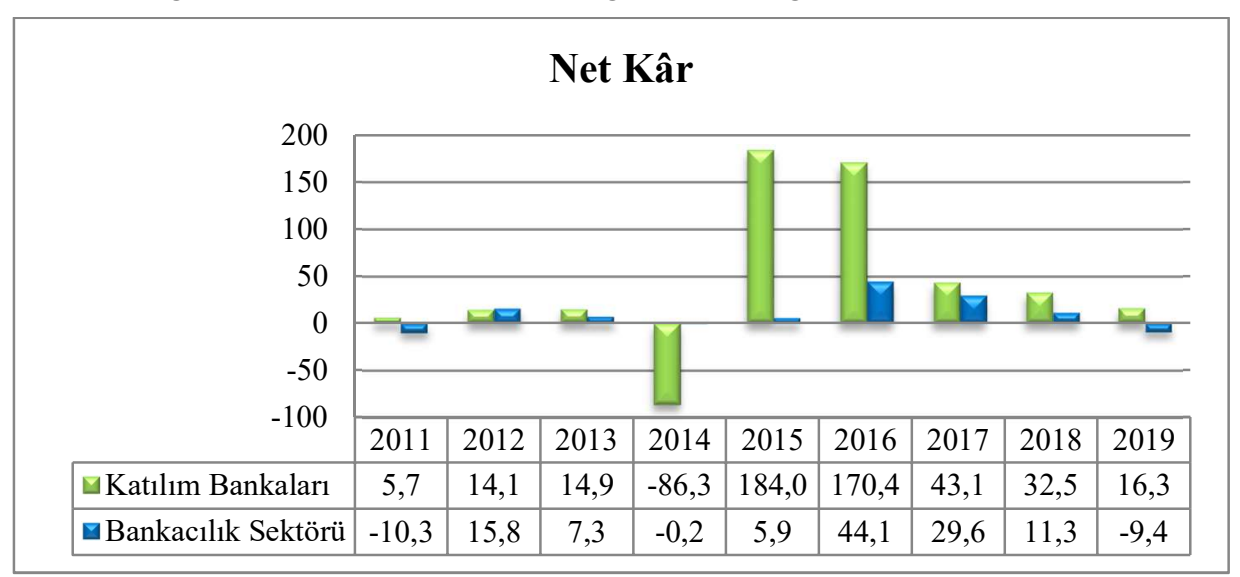

Kaynak: Tarafimızdan hazırlanmıştır.

Şekil 5. Katılım Bankaları ile Bankacılık Sektörünün Net Kârları (Büyüme Yüzdesi)

Şekil 6 incelendiğinde katılım bankalarının, bankacılık sektörü içerisinde 2014 y1lına kadar yükselen bir paya sahip olduğu görülmektedir. 2014 yılında ise Bank Asya'nın TMSF'ye devredilmesi ile katılım bankalarının sektördeki payları düşüş göstermeye başlamış ve takip eden 2015 yılında da kârlılık dışındaki bütün verilerde en düşük seviyeler görülmüştür. 2015 yılından itibaren kamu sermayeli üç katılım bankasının sektöre giriş yapması ile birlikte katılım bankalarının bankacılık sektöründeki payları tekrar yükselişe geçmiştir. Bu gelişim neticesinde katılım bankaları 2019 y1lsonu itibariyle aktif toplamı, fon toplamı ve net kâr kalemlerinde yıllar itibariyle en yüksek paya ulaşmışlardır. 


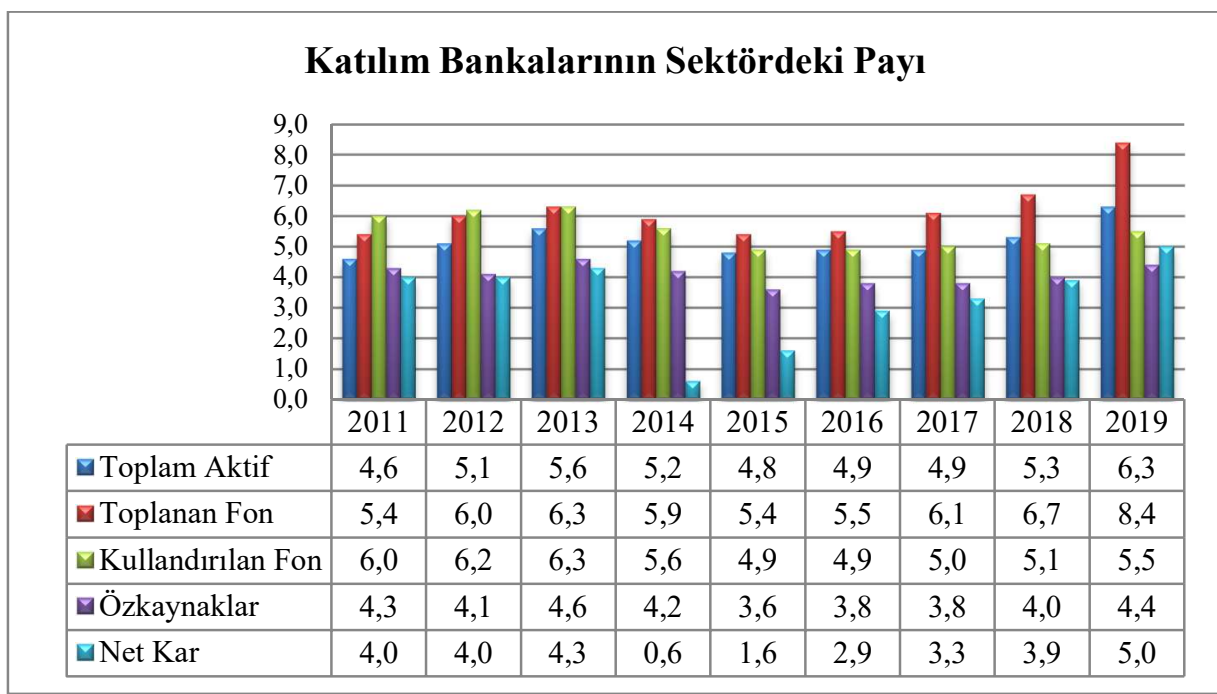

Kaynak: Tarafimızdan hazırlanmıştır.

Şekil 6. Katılım Bankalarının Bankacıllk Sektöründeki Payları

\section{Literatür Taraması}

Katılım bankacılığ 1 , müşterilerinden topladığ fonları direkt olarak reel sektöre yönlendirmesi ve ekonomiye yaptığı pozitif katkılar neticesinde giderek önem kazanarak bankacılık sektöründe de yükselen bir paya sahip olmaktadır. Bu bağlamda son yıllarda katılım bankacılığı bir başka deyişle faizsiz finans hem yerli hem de yabancı araştırmacılar tarafından dikkat çekici bir olgu olarak görülmüş ve birçok farklı araştırmaya konu olmuştur.

Samad (2004), Bahreyn'de faaliyet gösteren İslami bankalar ile konvansiyonel bankaların körfez savaşı sonrasındaki finansal performanslarını ölçmeyi amaçladığı çalışmasında; bankaların kârlılık, likidite riski ve kredi riski performanslarını ölçmüştür. Kârlılık performansı için aktif kârlılık, öz kaynak kârlılı̆̆1 ve toplam maliyet/toplam gelir oranlarını; likidite riski için toplam krediler/aktif toplamı, likit aktifler/mevduat ve kısa vadeli fon toplamı oranı ile toplam krediler/mevduat ve borç toplamı oranlarını; kredi riski için ise öz kaynak/aktif toplamı, öz kaynak/ toplam krediler ve takipteki krediler/toplam krediler oranlarını Student's t-testi ile analiz etmiştir. 1991-2001 yılları arasındaki verilerle yapılan analizler neticesinde, İslami bankalar ile konvansiyonel bankalar arasında kârlılık ve likidite riski açısından büyük farklılıklar olmadığı sonucuna varılırken, kredi riski performansında ise İslami bankaların konvansiyonel bankalara göre daha az kredi riskine maruz kaldıkları sonucu ortaya konmuştur.

Yudistira (2004) çalışmasında, 12 farklı ülkede faaliyet gösteren 18 İslami bankanın 1997-2000 yılları arasındaki verilerini, veri zarflama yöntemi ile analiz etmiş̧tir. Toplam krediler, diğer gelirler ve likit varlıkları çıktı; personel giderleri, sabit varlıklar ve mevduat toplamını ise girdi olarak analize dahil ettiği 


\section{Katılım Bankalarının Finansal Performans Analizi}

çalışmasında 1998 ile 1999 yılları arasında İslami bankaların verimli ve istikrarlı olup olmadıklarını araştırmıştır. Araştırma neticesinde, küresel kriz yılları olmasına rağmen örnekleme dâhil olan İslami bankaların performanslarının çok iyi olduğu ve bu bankalarda verimsizliğin düşük olduğu sonucuna ulaşılmıştır.

Safiullah (2010) çalışmasında, Bangladeş'te faaliyet gösteren 4 faizsiz İslami banka ve 4 ticari bakanın 2004 ile 2008 yılları arasındaki performans üstünlüklerini ölçmeyi amaçlamıştır. Bankaların finansal performans göstergeleri olarak kârlılık, likidite ve borç ödeme gücü, ekonomiye ve topluma bağl1lık, etkinlik ve verimlilik gibi kıstasları değerlendirmeye tabi tutmuştur. Çalışma sonucunda, faiz temelli geleneksel bankaların İslami bankalardan daha iyi bir performans sergilediği sonucuna ulaşılmıştır. Bunun yanında, İslami bankaların iş geliştirme, kârlılık, likidite ve borç ödeme gücü açısından performansının, faiz temelli klasik bankalardan daha yüksek olduğu da bulunmuştur.

Onour ve Abdalla (2011), İslami bankaların performans düzeylerini tespit etmek amaciyla 2007-2008 döneminde Sudan'da faaliyet gösteren özel ve kamu sermayeli 12 tane İslami bankayı veri zarflama analizi tekniği ile incelemişlerdir. Birçok etkinlik ve verimlilik değişkenlerini analize dahi etmişler ve analiz sonucunda, banka sahipliğinin yönetim ve ölçek etkinliği kısıtlaması olmadığı; bankanın büyüklügünün ise ölçek etkinliği için önemli bir faktör olduğunu sonucuna varmışlardır.

Usman ve Khan (2012) ise çalışmalarında, Pakistan'da faaliyette bulunan 3 İslami banka ile 3 geleneksel bankanın 2007 ile 2009 yıllarındaki kârlılık ve likidite oranları karşıllaştırmak için t-testi yönteminden yararlanmışlardır. Çalışmanın sonucunda, İslami bankaların kârlılık ve likidite düzeylerinin geleneksel bankalara oranla daha yüksek olduğu sonucuna ulaşılmıştır.

2012 yılındaki çalışmasında Baykara (2012), Türkiye'de finans sektörü içinde gün geçtikçe gelişen ve büyüyen katılım bankalarının 2005 ile 2011 yılları arasındaki faaliyetlerinin etkinlik ve verimliliklerini TOPSIS tekniği ile tespit etmeyi amaçlamıştır. Çalışmanın sonucuna göre; verimli olan bir katılım bankasının aynı zamanda etkin olmadığı ortay çıkmıştır. Ayrıca bir katılım bankasının yatırım araçlarını çeşitlendirmesi neticesinde verimlilik ve etkinliğimde gözle görülür bir artış sağladığı görülmüştür.

Doğan (2013) ise çalışmasında, katılım ve geleneksel bankaların 2005 ile 2011 yılları arasındaki finansal performanslarını çeşitli oranlar (likidite, kârlılık, borç ödeme gücü, risklilik ve sermaye yeterlilik) kullanarak karşıllaştırmıştır. Ampirik analizlerde analize dâhil edilen bankalar arasındaki farklığın tespit edilmesi için t-testinden yararlanmıştır. Analiz sonucunda, ticari bankaların daha likit, borç ödeme gücü daha yüksek ve bu bankalarda risk unsurunun daha az olduğunu fakat kârlılık açısından katılım ve ticari bankalar arasında bir farklılık olmadığını ileri sürmüştür.

Rozzani ve Abdul Rahman (2013) çalışmalarında, Malezya'da faaliyet gösteren 19 konvasiyonel banka ve 16 katılım bankası olmak üzere toplam 35 bankanın 2008-2011 yılları arasındaki verilerini analiz etmişlerdir. Analiz 
sonuçlarına göre sermaye yeterliliği ve kârlılıkta konvansiyonel bankalar daha yüksek performansa sahip çıkmıştır. Bunun yanında kredi riski ile katılım bankalarının performansı arasında pozitif bir ilişki tespit etmişlerdir.

Buğan (2015) çalışmasında, katılım bankalarının mevduat bankalara oranla kaynaklarını daha etkin kullanıp kullanmadığını tespit etmeyi amaçlamıştır. Türkiye'de faaliyet gösteren mevduat bankaları ile katılım bankalarını 2006 ile 2012 yılları arasındaki verileri, veri zarflama yöntemi ile analiz edilmiştir. Çalışma sonucunda, katılım bankalarının mevduat bankalarına göre kaynaklarını daha etkin kullandığı tespit edilmiştir.

Toraman vd. (2015) çalışmalarında, mevduat ve katılım bankalarının 2006 ile 2014 yılları arasındaki performanslarını karşılaştırmalı bir şekilde analiz etmiş̧lerdir. Analiz yöntemi olarak t-testi ve genelleştirilmiş momentler metodu kullanılmışıı. Çalışmanın sonucunda, mevduat bankalarının aktif kârlılıklarının katılım bankalarından daha yüksek olduğu ve sermaye yeterliliği açısından mevduat bankalarının katılım bankalarına göre daha güçlü bir yapıya sahip olduğu sonucuna ulaşılmıştır.

Esmer ve Bağc1 (2016) çalışmalarında, Türkiye bankacılık sektöründe yer alan katılım bankalarının 2005-2014 yılları arasındaki finansal performans ölçümlerini TOPSIS yöntemini kullanarak ölçmeyi amaçlamıştır. Yapılan analizler sonucunda, Türkiye'deki katılım bankaları arasında en yüksek finansal performansa sahip olan katılım bankasının Bank Asya olduğu sonucuna varılmıştır.

Pehlivan (2016) çalışmasında, katılım bankaları ile mevduat bankalarının karşılaştırmasını yapmıştır. Bunun yanında katılım bankalarının bankacılık sektörü içindeki önemini ortaya koymayı da amaçlamıştır. Bu amaçla 2006-2014 yıllarına ilişkin çeşitli büyüklükleri (aktif toplamı, öz kaynaklar, net kâr, toplanan fonlar, kullandırılan fonlar, şube ve personel sayısı) ve oranları (kârlılık oranları, gelir-gider oranları ve sermaye yeterlilik rasyosu) kullanarak değerlendirme yapmıştır. Yapılan değerlendirmeler neticesinde, katılım bankalarının bankacılık sektörü içerisinde giderek artan bir öneme ve paya sahip olduğu sonucuna ulaşılmıştır.

Bozdoğan vd. (2018) yaptıkları çalışmalarında, katılım bankalarının finansal performanslarını ölçmek amacıyla, CAMELS değerlendirme sistemine göre belirlenen rasyoları TOPSIS yöntemi ile analiz etmişlerdir. Analizde, beş katılım bankasının 2016 yılı son çeyreği ile 2017 yılının dört çeyreğine ilişkin veriler kullanılmış ve bu beş döneme ilişkin bankaların başarı sıralamasının yapılması amaçlanmıştır. Yapılan analizler sonucunda ilgili dönemde en yüksek finansal performansı gösteren banka Türkiye Finans Katılım Bankası, en düşük performansa sahip banka ise Ziraat Katılım Bankası ise olarak tespit edilmiştir.

Çağıran Kendirli vd. (2019) ise çalışmalarında, üç katılım bankası ile 10 ticari bankanın mali performanslarını analiz etmişlerdir. Araştırma kapsamında bankaların kriz öncesi dönem (2005-2008), kriz dönemi (2008-2011) ve kriz sonrası dönem (2011-2015) olmak üzere üç farklı dönemdeki performansları 


\section{Katılım Bankalarının Finansal Performans Analizi}

TOPSIS yöntemi ile analiz edilmiştir. Analiz sonucunda, kriz öncesi dönem ve kriz sonrası dönemde ticari bankaların mali performanslarının daha iyi olduğu, kriz döneminde ise katılım bankalarının daha iyi performans gösterdiği görülmüştür.

\section{Yöntem}

\section{A. Araştırmanın Amacı ve Kapsamı}

$\mathrm{Bu}$ çalışmanın amacı, Türkiye'de faaliyet gösteren katılım bankalarının 2011-2019 yılları arasındaki finansal performanslarının analizini yaparak yıllar itibariyle katılım bankaları arasında daha yüksek performansa sahip olanları tespit etmektir. Çalışma, 2011 ile 2019 yılları arasında faaliyet gösteren yedi katılım bankasından elde edilen verileri kapsamaktadır. 2019 yılında tüm bankaların yılsonu verileri yayınlanmadığı için, ilgili yılda 9 aylık veriler analize dâhil edilmiştir. Katılım bankalarına ilişkin veriler Türkiye Katılım Bankaları Birliği internet sitesi ve ilgili katılım bankalarının kendi internet sitelerinden elde edilmiştir.

\section{B. Araştırmanin Modeli}

Çalışmamızda katılım bankalarının finansal performanslarının ölçülebilmesi için TOPSIS yöntemi kullanılmıştır. Bu yöntem neticesinde elde edilen finansal performans puanlarına göre katılım bankaları hakkında değerlendirmeler yapılmıştır. TOPSIS yöntemi ile finansal performans puanlarının hesaplanması amacıyla birtakım rasyolar kullanılmıştır. Bu rasyolar Esmer ve Bağcı (2016)'nın çalışmalarından alınmış olup aşağıdaki gibidir:

- Aktif Kârlılığ1,

- Öz kaynak Kârlılığı,

- Öz kaynaklar/Toplam Aktifler,

- Net Kâr Payı Geliri/Toplam Aktifler,

$\mathrm{Bu}$ rasyolar, kârlılık oranları ve borçlanma oranlarının alt başlıklarıdır. $\mathrm{Bu}$ rasyoların seçilmesinin nedeni, kârlılık oranlarının bankaların finansal performansının artışını göstermesi, öz kaynak ve kredi oranlarının ise bankaların sıkıntıya düşmemesi için belirleyici finansal performans göstergeleri olmasıdır.

Katılım bankalarına ilişkin bulunan rasyolar bankalar itibari ile aşağıdaki tablolarda gösterilmiştir. Albaraka Türk, Kuveyt Türk ve Türkiye Finans katılım bankalarının 7 yıla ilişkin hesaplanan rasyoları tablolarda yer alırken; Bank Asya' ya iliş̧kin 2011-2014 yılları arasındaki rasyolar tablolara eklenmiştir. 2015 yılında Bank Asya'nın BDDK tarafından faaliyet izninin kaldırılmasından dolayı bu yıldan itibaren Bank Asya analizden çıkarılmıştır. Bunun yanında Ziraat Katılım Bankası 2015, Vakıf Katılım Bankası 2016 ve Emlak Katılım Bankası ise 2019 yılından itibaren faaliyete başladıkları için bu tarihlerden itibaren analize dâhil edilmişlerdir. Katılım bankalarına ilişkin hesaplanan rasyolar aşağıdaki gibidir: 
Tablo 2. Albaraka Türk Katılım Bankası Finansal Rasyoları

\begin{tabular}{lccccccccc}
\hline RASYOLAR & $\mathbf{2 0 1 1}$ & $\mathbf{2 0 1 2}$ & $\mathbf{2 0 1 3}$ & $\mathbf{2 0 1 4}$ & $\mathbf{2 0 1 5}$ & $\mathbf{2 0 1 6}$ & $\mathbf{2 0 1 7}$ & $\mathbf{2 0 1 8}$ & $\begin{array}{c}\mathbf{2 0 1 9 / 9} \\
\text { aylık }\end{array}$ \\
\hline Aktif Kârlılı̆̆ı & 0,015 & 0,016 & 0,014 & 0,011 & 0,010 & 0,007 & 0,007 & 0,003 & 0,000 \\
\hline $\begin{array}{l}\text { Öz kaynak } \\
\text { Kârlılı̆̆ı }\end{array}$ & 0,159 & 0,157 & 0,161 & 0,141 & 0,144 & 0,095 & 0,096 & 0,041 & 0,004 \\
\hline $\begin{array}{l}\text { Öz kaynaklar } \\
\text { /Toplam Aktifler }\end{array}$ & 0,096 & 0,099 & 0,087 & 0,078 & 0,071 & 0,069 & 0,068 & 0,077 & 0,070 \\
\hline $\begin{array}{l}\text { Net Kâr Payı } \\
\text { Geliri/Toplam }\end{array}$ & 0,037 & 0,039 & 0,036 & 0,030 & 0,030 & 0,031 & 0,035 & 0,024 & 0,010 \\
\begin{tabular}{l} 
Aktifler \\
\hline $\begin{array}{l}\text { Vergi Öncesi } \\
\text { Kâr/Pasif Toplamı }\end{array}$
\end{tabular} & 0,019 & 0,020 & 0,017 & 0,014 & 0,013 & 0,008 & 0,008 & 0,004 & 0,000 \\
\hline $\begin{array}{l}\text { Takipteki } \\
\text { Krediler/ Toplam } \\
\text { Krediler }\end{array}$ & 0,024 & 0,025 & 0,023 & 0,021 & 0,025 & 0,051 & 0,050 & 0,070 & 0,074 \\
\hline $\begin{array}{l}\text { Toplam Krediler/ } \\
\text { Toplam Aktifler }\end{array}$ & 0,694 & 0,735 & 0,696 & 0,671 & 0,628 & 0,665 & 0,675 & 0,641 & 0,646 \\
\hline
\end{tabular}

Tablo 3. Kuveyt Türk Katılım Bankası Finansal Rasyoları

\begin{tabular}{|c|c|c|c|c|c|c|c|c|c|}
\hline RASYOLAR & 2011 & 2012 & 2013 & 2014 & 2015 & 2016 & 2017 & 2018 & $\begin{array}{c}\text { 2019/9 } \\
\text { aylık }\end{array}$ \\
\hline Aktif Kârlılığı & 0,013 & 0,013 & 0,012 & 0,011 & 0,011 & 0,011 & 0,012 & 0,012 & 0,008 \\
\hline $\begin{array}{l}\text { Öz kaynak } \\
\text { Kârlılığı }\end{array}$ & 0,136 & 0,149 & 0,130 & 0,123 & 0,131 & 0,139 & 0,147 & 0,160 & 0,122 \\
\hline $\begin{array}{l}\text { Öz kaynaklar/ } \\
\text { Toplam Aktifler }\end{array}$ & 0,097 & 0,089 & 0,089 & 0,089 & 0,081 & 0,081 & 0,080 & 0,073 & 0,066 \\
\hline $\begin{array}{l}\text { Net Kâr Payı } \\
\text { Geliri/Toplam } \\
\text { Aktifler }\end{array}$ & 0,036 & 0,037 & 0,032 & 0,034 & 0,035 & 0,034 & 0,022 & 0,042 & 0,026 \\
\hline $\begin{array}{l}\text { Vergi Öncesi Kâr/ } \\
\text { Pasif Toplamı }\end{array}$ & 0,016 & 0,016 & 0,014 & 0,014 & 0,013 & 0,014 & 0,015 & 0,015 & 0,010 \\
\hline $\begin{array}{l}\text { Takipteki Krediler/ } \\
\text { Toplam Krediler }\end{array}$ & 0,020 & 0,024 & 0,024 & 0,023 & 0,017 & 0,026 & 0,020 & 0,026 & 0,045 \\
\hline $\begin{array}{l}\text { Toplam Krediler/ } \\
\text { Toplam Aktifler }\end{array}$ & 0,689 & 0,619 & 0,627 & 0,605 & 0,615 & 0,586 & 0,631 & 0,611 & 0,499 \\
\hline
\end{tabular}

Tablo 4. Türkiye Finans Katılım Bankası Finansal Rasyoları

\begin{tabular}{lccccccccc}
\hline RASYOLAR & $\mathbf{2 0 1 1}$ & $\mathbf{2 0 1 2}$ & $\mathbf{2 0 1 3}$ & $\mathbf{2 0 1 4}$ & $\mathbf{2 0 1 5}$ & $\mathbf{2 0 1 6}$ & $\mathbf{2 0 1 7}$ & $\mathbf{2 0 1 8}$ & $\begin{array}{c}\mathbf{2 0 1 9 / 9} \\
\text { aylık }\end{array}$ \\
\hline Aktif Kârılı̆̆ı & 0,017 & 0,016 & 0,013 & 0,010 & 0,007 & 0,008 & 0,010 & 0,009 & 0,004 \\
\hline \begin{tabular}{l} 
Öz kaynak Kârıı̆ı̆ı \\
\hline$\ddot{\# ̈ z ~ k a y n a k l a r / ~}$
\end{tabular} & 0,144 & 0,133 & 0,131 & 0,106 & 0,078 & 0,081 & 0,092 & 0,103 & 0,045 \\
$\begin{array}{l}\text { Toplam Aktifler } \\
\text { Net Kâr Payı Geliri/ } \\
\text { Toplam Aktifler }\end{array}$ & 0,042 & 0,045 & 0,035 & 0,033 & 0,036 & 0,039 & 0,037 & 0,037 & 0,028 \\
\hline $\begin{array}{l}\text { Vergi Öncesi Kâr/ } \\
\text { Pasif Toplamı }\end{array}$ & 0,022 & 0,016 & 0,016 & 0,013 & 0,009 & 0,010 & 0,012 & 0,012 & 0,005 \\
$\begin{array}{l}\text { Takipteki Krediler/ } \\
\text { Toplam Krediler }\end{array}$ & 0,024 & 0,028 & 0,025 & 0,026 & 0,046 & 0,054 & 0,056 & 0,057 & 0,078 \\
\hline $\begin{array}{l}\text { Toplam Krediler/ } \\
\text { Toplam Aktifler }\end{array}$ & 0,765 & 0,725 & 0,694 & 0,688 & 0,700 & 0,660 & 0,648 & 0,648 & 0,577 \\
\hline
\end{tabular}


Katılım Bankalarının Finansal Performans Analizi

Tablo 5. Asya Finans Katılım Bankası Finansal Rasyoları

\begin{tabular}{lcccc}
\hline RASYOLAR & $\mathbf{2 0 1 1}$ & $\mathbf{2 0 1 2}$ & $\mathbf{2 0 1 3}$ & $\mathbf{2 0 1 4}$ \\
\hline Aktif Kârlıı̆̆ı & 0,013 & 0,009 & 0,007 & $-0,059$ \\
\hline Öz kaynak Kârlılı̆̆ı & 0,101 & 0,081 & 0,072 & $-0,477$ \\
\hline Öz kaynaklar/Toplam Aktifler & 0,124 & 0,110 & 0,090 & 0,125 \\
\hline Net Kâr Payı Geliri/Toplam Aktifler & 0,037 & 0,041 & 0,035 & 0,049 \\
\hline Vergi Öncesi Kâr/Pasif Toplamı & 0,016 & 0,011 & 0,008 & $-0,061$ \\
\hline Takipteki Krediler/Toplam Krediler & 0,047 & 0,040 & 0,056 & 0,197 \\
\hline Toplam Krediler/Toplam Aktifler & 0,765 & 0,749 & 0,745 & 0,662 \\
\hline
\end{tabular}

Tablo 6. Ziraat Katılım Bankası Finansal Rasyoları

\begin{tabular}{lccccc}
\hline RASYOLAR & $\mathbf{2 0 1 5}$ & $\mathbf{2 0 1 6}$ & $\mathbf{2 0 1 7}$ & $\mathbf{2 0 1 8}$ & $\begin{array}{c}\mathbf{2 0 1 9 /} \\
\mathbf{9} \text { aylık }\end{array}$ \\
\hline Aktif Kârlıı̆ıı & $-0,006$ & 0,004 & 0,011 & 0,015 & 0,013 \\
\hline Öz kaynak Kârlılı̆̆ı & $-0,018$ & 0,040 & 0,113 & 0,147 & 0,129 \\
\hline Öz kaynaklar/Toplam Aktifler & 0,305 & 0,096 & 0,098 & 0,100 & 0,097 \\
\hline Net Kâr Payı Geliri/Toplam Aktifler & 0,031 & 0,026 & 0,031 & 0,039 & 0,030 \\
\hline Vergi Öncesi Kâr/Pasif Toplamı & $-0,005$ & 0,005 & 0,014 & 0,019 & 0,016 \\
\hline Takipteki Krediler/Toplam Krediler & 0,000 & 0,002 & 0,003 & 0,014 & 0,021 \\
\hline Toplam Krediler/Toplam Aktifler & 0,776 & 0,698 & 0,793 & 0,777 & 0,815 \\
\hline
\end{tabular}

Tablo 7. Vakıf Katılım Bankası Finansal Rasyoları

\begin{tabular}{lcccc}
\hline RASYOLAR & $\mathbf{2 0 1 6}$ & $\mathbf{2 0 1 7}$ & $\mathbf{2 0 1 8}$ & $\begin{array}{c}\mathbf{2 0 1 9 /} \\
\mathbf{9 y l} \mathbf{\text { ayk }}\end{array}$ \\
\hline Aktif Kârlılı̆̆ı & 0,004 & 0,010 & 0,016 & 0,009 \\
\hline Öz kaynak Kârlılı̆̆ı & 0,022 & 0,125 & 0,213 & 0,138 \\
\hline Öz kaynaklar/Toplam Aktifler & 0,187 & 0,084 & 0,073 & 0,068 \\
\hline Net Kâr Payı Geliri/Toplam Aktifler & 0,021 & 0,020 & 0,029 & 0,016 \\
\hline Vergi Öncesi Kâr/Pasif Toplamı & 0,006 & 0,013 & 0,020 & 0,013 \\
\hline Takipteki Krediler/Toplam Krediler & 0,001 & 0,002 & 0,018 & 0,031 \\
\hline Toplam Krediler/Toplam Aktifler & 0,629 & 0,726 & 0,647 & 0,569 \\
\hline
\end{tabular}

Tablo 8. Emlak Katılım Bankası Finansal Rasyoları

\begin{tabular}{lc}
\hline \multicolumn{2}{c}{ Tablo 8. Emlak Katılım Bankası Finansal Rasyoları } \\
\hline RASYOLAR & $\mathbf{2 0 1 9 /}$ \\
\hline Aktif Kârlılı̆̆ı & 0,005 \\
\hline Öz kaynak Kârlılı̆̆ı & 0,025 \\
\hline Öz kaynaklar/Toplam Aktifler & 0,186 \\
\hline Net Kâr Payı Geliri/Toplam Aktifler & 0,024 \\
\hline Vergi Öncesi Kâr/Pasif Toplamı & 0,006 \\
\hline Takipteki Krediler/Toplam Krediler & 0,053 \\
\hline Toplam Krediler/Toplam Aktifler & 0,573 \\
\hline
\end{tabular}

C. TOPSIS Yöntemi ile Finansal Performans Analizi

Çoklu karar verme yöntemleri içerisinde yer alan TOPSIS (Technique for Order Preference by Similarity to an Ideal Solution), giderek artan yoğun rekabet ortamında bütün işletmeler için önemli bir performans değerlendirme yöntemidir. 
$\mathrm{Bu}$ amaçla birçok alanda bu yöntem ile çalışmalar yapılmakta ve bu yöntemin önemi giderek artmaktadır (Soba ve Eren, 2011: 29).

İlk kez 1981 y1lında Yoon ve Hwang tarafindan kullanılan TOPSIS yöntemi sayesinde az sayıda girdi ile anlaşılabilir sonuçlar ortaya çıkarılabilmektedir. Bu yöntemin temelinde alternatiflerin ideal çözüme yakın olması ve ideal olmayan çözüme ise uzak olması yatmaktadır (Lai vd., 1994: 495). TOPSIS yöntemi ile alternatifler arasından, ideal çözüme yakın, negatif ideal çözüme uzak olan seçenek seçilir (Özdemir, 2014: 136).

TOPSIS yöntemi ile alternatiflerin belirli kriterler doğrultusunda sıralaması yapılmaktadır. Bu yöntemde ilk adım olarak karar matrisi oluşturulur. İkinci adımda ise karar matrisi normalize edilir ve üçüncü adımda bu karar matrisi ağırlıklandırılır. Dördüncü adımda pozitif ve negatif ideal çözümler oluşturulur ve devamında bu çözümlere olan uzaklıklar hesaplanır. En son adımda ise her bir alternatifin göreceli puanları hesaplanarak alternatiflerin sıralaması gerçekleştirilir (Dumanoğlu ve Ergül, 2010; Özdemir, 2014; Uzun ve Kazan, 2016).

TOPSIS yöntemi sonucunda katılım bankalarının 2011 ile 2019 yıllarına ilişkin elde edilen finansal performans puanları tablo 9'da gösterilmiştir.

Tablo 9. Katılım Bankalarının Finansal Performans Puanlar

\begin{tabular}{cccccccc}
\hline YILLAR & $\begin{array}{c}\text { Albaraka } \\
\text { Türk }\end{array}$ & $\begin{array}{c}\text { Kuveyt } \\
\text { Türk }\end{array}$ & $\begin{array}{c}\text { Türkiye } \\
\text { Finans }\end{array}$ & $\begin{array}{c}\text { Asya } \\
\text { Finans }\end{array}$ & $\begin{array}{c}\text { Ziraat } \\
\text { Katılım }\end{array}$ & $\begin{array}{c}\text { Vakıf } \\
\text { Katılım }\end{array}$ & $\begin{array}{c}\text { Emlak } \\
\text { Katılım }\end{array}$ \\
\hline $\mathbf{2 0 1 1}$ & 0,385 & 0,202 & 0,450 & 0,588 & - & - & - \\
\hline $\mathbf{2 0 1 2}$ & 0,605 & 0,468 & 0,668 & 0,394 & - & - & - \\
\hline $\mathbf{2 0 1 3}$ & 0,550 & 0,425 & 0,503 & 0,454 & - & - & - \\
\hline $\mathbf{2 0 1 4}$ & 0,678 & 0,682 & 0,681 & 0,322 & - & - & - \\
\hline $\mathbf{2 0 1 5}$ & 0,657 & 0,636 & 0,635 & - & 0,291 & - & - \\
\hline $\mathbf{2 0 1 6}$ & 0,543 & 0,629 & 0,602 & - & 0,138 & 0,295 & - \\
\hline $\mathbf{2 0 1 7}$ & 0,600 & 0,460 & 0,742 & - & 0,358 & 0,275 & - \\
\hline $\mathbf{2 0 1 8}$ & 0,401 & 0,528 & 0,549 & - & 0,540 & 0,585 & - \\
\hline $\mathbf{2 0 1 9} / 9$ & 0,246 & 0,559 & 0,423 & - & 0,679 & 0,572 & 0,452 \\
aylık & 0 & & & & & & - \\
\hline
\end{tabular}

Tablo 9'da katılım bankalarının TOPSIS yöntemi ile bulunmuş finansal performans puanları yıllar itibariyle gösterilmektedir. Bulunan finansal performans puanları 0 ile 1 arasında yer almaktadır. Puan 0'a yaklaştıkça finansal performansı düşük; 1'e yaklaştıkça finansal performansı yüksek olarak kabul edilmektedir. Tabloda "yeşil renk" ile belirtilen puanlar ilgili y1ldaki en yüksek finansal performans puanını, "kırmızı renk" ile belirtilen puanlar ise ilgili yıldaki en düşük finansal performans puanını göstermektedir. Bu bilgiler ışığında Tablo 9 incelendiğinde; 2011 yılında en yüksek puana sahip olan banka Bank Asya olarak karşımıza çıkmaktadır. Bank Asya'yı sırasıyla Türkiye Finans, Albaraka Türk ve Kuveyt Türk takip etmektedir. 2012 yllında ise Türkiye Finans performans puanları sıralamasında birincilikte yer alırken, Albaraka Türk ikinci, 


\section{Katılım Bankalarının Finansal Performans Analizi}

Kuveyt Türk üçüncü ve Bank Asya dördüncü olmuştur. 2013 yılında Albaraka Türk birinci, Türkiye Finans ikinci, Bank Asya üçüncü ve Kuveyt Türk dördüncü olmuştur. 2014 yılına gelindiğinde Bank Asya haricindeki katılım bankalarının finansal performans puanları birbirine yakın iken (Kuveyt Türk $=0,682$ - Türkiye Finans $=0,681$ - Albaraka Türk=0,678); Bank Asya ise TMSF'ye devredilmesi ve yılı zararla kapatması sonucunda rakiplerinden çok düşük bir puan $(0,322)$ almıştır. 2015 yılında bir önceki yılda olduğu gibi üç katılım bankasının puanları birbirine yakın çıkmış ve bulunan puanlara göre; Albaraka Türk birinci, Kuveyt Türk ikinci, Türkiye Finans üçüncü ve faaliyete yeni başlayan Ziraat Katılım Bankası ise dördüncü sırada yer almıştır. 2016 yılında ise katılım bankaları arasına Vakıf Katılım Bankası'nın da katılması ile analize dâhil edilen katılım bankası sayısı beşe yükselmiştir. 2016 yılında Kuveyt Türk 0,629 puan ile birinci, Türkiye Finans 0,602 puan ile ikinci, Albaraka Türk 0,543 puan ile üçüncü, Vakıf Katılım Bankası 0,295 puan ile dördüncü ve Ziraat Katılım Bankası 0,138 puan ile beşinci sırada yer almıştır. 2017 y1lında ise Türkiye Finans 0,742 performans puanı ile birinci olurken, Vakıf Katılım Bankası ise 0,275 puan ile beşinci olmuştur. 2018 yılında elde edilen puanlara göre; Vakıf Katılım Bankası ilk sırada yer alırken, Türkiye Finans Katılım Bankası ile Ziraat Katılım Bankası ikinci ve üçüncü sırayı almışlardır. 2018 yılında en düşük finansal performans puanına sahip olan katılım bankaları sırasıyla, Albaraka Türk Katılım Bankası ve Kuveyt Türk Katılım Bankası olarak tespit edilmiştir. 2019 yılına gelindiğinde ise Emlak Katılım Bankası'nın faaliyete başlaması ile birlikte altı katılım bankasının verileri analiz kapsamında değerlendirilmiştir. 2019 yılı 9 aylık verileri ile yapılan analizler neticesinde, bu dönemde en yüksek finansal performansa sahip olan banka Ziraat Katılım Bankası $(0,679)$, en düşük finansal performansa sahip banka ise Albaraka Türk Katılım Bankas1 $(0,246)$ olarak belirlenmiştir.

\section{Sonuç}

Son yıllarda giderek daha geniş kitlelere hitap etmeye başlayan İslami finans, İslam ülkelerinin dışında diğer ülkelerde de yer alan ve büyüme trendi içinde olan bir sektördür. İslami finans sektörü içerisinde önemli bir yere sahip olan katılım bankaları; farklı sebeplerle ekonomik döngü içerisinde kendisine yer bulamayan, ekonomiye dâhil edilememiş atıl fonları faizsiz bankacılık prensipleri içerisinde sisteme entegre etmelerinden dolayı geleneksel bankalara bir alternatif oluşturarak geleneksel bankacılık sektörünün çeşitlenmesini sağlamışlardır. Ayrıca katılım bankalarının gelir dağılımını düzeltmek, reel sektöre kaynak sağlamak, kayıt dışı ekonomiyi azaltmak ve istihdam imkânlarını artırmak gibi ekonomiye önemli katk1larda da bulunmaktadır.

$\mathrm{Bu}$ çalışmada Türk bankacılık sektöründe faaliyet gösteren katılım bankalarını 2011 ile 2019 yılları arasındaki finansal performansları TOPSIS yöntemi ile analiz edilmiştir. Yapılan analizler sonucunda katılım bankaları arasında en yüksek finansal performansa sahip olan banka Türkiye Finans 
Katılım Bankası olmuştur. İkinci sırada Albaraka Türk Katılım Bankası ve üçüncü sırada ise Kuveyt Türk Katılım bankası yer almaktadır. Bank Asya ise, 2014 y1lında TMSF'ye devredilmesi ve 2015 y1lında ise faaliyet izninin kaldırılmasından dolayı finansal performans puanları açısından bu üç katılım bankasının gerisinde kalmıştır. Ziraat Katılım Bankası, Vakıf Katılım Bankası ve Emlak Katılım Bankası'nın ise henüz yeni kurulan bankalar olmalarından dolayı ilk yıllarında yüksek finansal performans puanlarını alamadıkları, ancak 2018 ve 2019 yıllarında gelişme gösterdikleri gözlenmiştir.

Türkiye'de katılım bankaları, düzenli olarak artan bir büyüme oranı ile faaliyetlerine devam etmekte ve bankacılık sektöründen aldığı payı her yıl daha da artırmaktadır. Buna rağmen bankacılık sektörü dolayısıyla da finans sektörü içerindeki rolü gün geçtikçe artan katılım bankalarının henüz arzu edilen seviyelerde olmadığı görülmektedir. Katılım bankalarının istenilen seviyelere çıkabilmeleri için güçlü bir finansal yapıya sahip olmaları zorunludur. Güçlü bir finansal yapı için yeterli seviyede öz kaynak yapısı ile birlikte toplanan fonların da sürekli gelişim trendinde olması son derece önem taşımaktadır. Katılım bankaları son üç yılda öz kaynaklarını \%89,36 oranında artırırken, topladığı fonları ise \%159,65 oranında artırmıştır. Bu dönemde bankacılık sektöründe sırasıyla $\% 64$ ve $\% 76,51$ oranında artışlar gerçekleşmiştir. Bu sonuçlar, katılım bankalarının 2014-2015 döneminde yaşanan olumsuzlukları giderdiklerini ve gelişim trendlerini devam ettiklerini göstermektedir. Katılım bankalarının, 2025 yılında bankacılık sektöründen \%15 pay almak olarak belirledikleri hedefe ulaşmaları için kuşkusuz çok daha güçlü bir finansal yapıya sahip olmaları zorunludur. Finansal yapısı sağlam olan, doğabilecek riskler ve oluşabilecek muhtemel krizler karşısında sağlam durabilen katılım bankaları, ekonominin gelişmesine katkıda bulunurken kendi varlıklarını da sağlıklı bir şekilde devam ettirebileceklerdir.

Bu açıdan bakıldığında, katılım bankalarının ileri dönemlerde de yeterli öz kaynaklara sahip olmasının kamuoyunda getireceği güven ve itibarın derecesinde sektördeki paylarının artacağı beklenebilir. Son yıllarda kamu katılım bankalarının sektörde faaliyet göstermeye başlaması ve fon sahiplerine devlet güvencesinin hissettirilmesi, katılım bankalarının toplam fonlarda 2016 y1lından itibaren hızla artış göstermesinde etkili olduğu söylenebilir. Ancak toplanan fonlar ve artış yüzdeleri dikkate alındığında sektörün uzun vadede arzulanan büyümeyi desteklemekten uzak olduğu düşünülmektedir. Türkiye'de katılım bankacılığının küresel ölçekte belirlenen hedefler çizgisinde büyüyüp gelişebilmesi için bilançolarının aktif ve pasif yapılarındaki sınırlı sayıdaki finansal ürün yelpazesindeki alternatiflerin etkinliğinin ve çeşitliliğinin artırılması gereklidir. İstanbul'un finans merkezi olabilmesi bağlamında, küresel pazara da hitap edebilecek yeni finansal enstrümanlar oluşturulmalı veya ülkemizde kullanılmamakla birlikte Malezya ve Endonezya gibi tecrübeli ülkelerden yeni finansal ürünlerin ülkemize adaptasyonu ivedilikle sağlanmalıdır. 
Katılım Bankalarının Finansal Performans Analizi

\section{Kaynaklar}

Atar, A. (2017) "Başlangıcından Günümüze Dünyada ve Türkiye'de İslami Bankac1lı̆̆ın Genel Durumu", Journal of History Culture and Art Research, 6(4), ss. 1029-1062.

Baykara, H. V. (2012) Katılım Bankalarında Etkinlik ve Verimlilik Analizi, (Yüksek Lisans Tezi), Gaziosmanpaşa Üniversitesi, Sosyal Bilimler Enstitüsü, Tokat.

Bozdoğan, T., Ersoy, B. ve Kaygısız, M. (2018). "CAMELS Değerlendirme Sistemiyle Katılım Bankalarının Finansal Performanslarının TOPSIS Yöntemiyle Analizi”, Journal of Social And Humanities Sciences Research, 5(30), ss. 4309-4323.

Buğan, M. F. (2015). Katılım Bankalart ile Konvansiyonel Bankaların Etkinliklerinin VZA ve Malmquist TFV Endeksi ile Karşılaş̧tırlması, (Yüksek Lisans Tezi), Gaziantep Üniversitesi, Sosyal Bilimler Enstitüsü, Gaziantep.

Çağıran Kendirli, H., Kendirli, S. ve Aydın. Y. (2019). "Küresel Kriz Çerçevesinde Katılım Bankalarının ve Ticari Bankaların Mali Performanslarının TOPSİS Yöntemiyle Analizi”, Atatürk Üniversitesi Iktisadi ve İdari Bilimler Dergisi, 33(1), ss. 137-154.

Çobankaya F. T. (2014) Katılım Bankalarının Türkiye'deki Farkındalık Düzeyinin Tespiti: Batı Akdeniz Bölgesinde Bir Araştırma, (Yüksek Lisans Tezi), Süleyman Demirel Üniversitesi, Sosyal Bilimler Enstitüsü, Isparta.

Doğan, M. (2013). "Katılım ve Geleneksel Bankaların Finansal Performanslarının Karşılaştırılması: Türkiye Örneği", Muhasebe ve Finansman Dergisi, 58, ss. 175-188.

Dumanoğlu, S. ve Ergül, N. (2010) "iMKB'de İşlem Gören Teknoloji Şirketlerinin Mali Performans Ölçümü”, Mufad Journal, 48, ss. 101-111.

Esmer, Y. ve Bağcı, H. (2016) "Katılım Bankalarında Finansal Performans Analizi: Türkiye Örneği”, Mehmet Akif Ersoy Üniversitesi Sosyal Bilimler Enstitüsü Dergisi, 8(15), ss. 17-30.

Gökçen, G. ve Gönen, İ. (2017) "Katılım Bankalarının Finans Sektörü İçindeki Yeri Ve Katılım Bankalarına Yönelik Müşteri Algısı", Finans Ekonomi ve Sosyal Araştırmalar Dergisi, 2(1), ss. 61-77.

Kınalı, F. (2012). Faizsiz Sistemde Bankacılık Anlayışı ve Kredi Iş̧lemleri, (Yüksek Lisans Tezi), Selçuk Üniversitesi, Sosyal Bilimler Enstitüsü, Konya.

Lai, Y., Liu, T. and Hwang, C. (1994) "Topsis for MODM", European Journal of Operational Research, 76, pp. 486-500.

Nakiboğlu, A. ve Levent, M. (2018). "İslami Finans ve Katilim Bankacıllı̆̆: Türkiye ve Dünyadaki Uygulamaları", Turkish Studies, 13(7), 175-186. 
Onour, I. A. and Abdalla, A. M. A. (2011) "Efficiency of Islamic Banks in Sudan: A Non-parametric Approach", Journal of Islamic Economics, Banking and Finance, 7(4), pp. 79-92.

Özdemir M. (2014) Bölüm Adı: TOPSIS, Operasyonel, Yönetsel ve Stratejik Problemlerin Çözümünde Çok Kriterli Karar Verme Yöntemleri, ss. 133153, Dora Basım-Yayın Dağıtım: Bursa.

Özkan, H. (2012) Katılım Bankacıllı̆ııın Klasik Bankalarla Karşılaştırılması ve Muhasebe Uygulamalarl, (Yüksek Lisans Tezi), Niğde Üniversitesi, Sosyal Bilimler Enstitüsü, Niğde.

Pehlivan, P. (2016) “Türkiye' de Katılım Bankacılığı ve Bankacılık Sektöründeki Önemi. Makale”, Sosyal Ekonomik Araştırmalar Dergisi, 16(31), ss. 296324.

Rozzani, N. and Abdul Rahman, R. (2013). "Camels and Performance Evaluation of Banks in Malaysia: Conventional Versus Islamic", Journal of Islamic Finance and Business Research, 2(1), pp. 36-45.

Safiullah, M. (2010) "Superiority of Conventional Banks \& Islamic Banks of Bangladesh: A Comparative Study", International Journal of Economics and Finance, 2(3), pp. 199-207.

Samad, A. (2004). "Performance of Interest-Free Islamic Banks vis-à-vis Interest-Based Conventional Banks of Bahrain", IIUM Journal of Economics and Management, 12(2), ss.1-15.

Soba, M. ve Eren, K. (2011). “Topsis Yöntemini Kullanarak Finansal Ve Finansal Olmayan Oranlara Göre Performans Değerlendirilmesi, Şehirlerarası Otobüs Sektöründe Bir Uygulama”, Sosyal ve Ekonomik Araştırmalar Dergisi, 11(21), ss. 23-40.

T.C. Cumhurbaşkanlığı Strateji ve Bütçe Başkanlığı. (2019). On birinci kalkınma planı (2019-2023). Erişim adresi: http://www.sbb.gov.tr/wpcontent/uploads/2019/11/ON_BIRINCI_KALKINMA-PLANI_20192023.pdf

T.C. Kalkınma Bakanlığı. (2017). Orta vadeli program (2018-2020). Erişim adresi:http://www.kalkinma.gov.tr/Lists/OrtaVadeliProgramlar/Attachme nts/14/Orta_Vadeli_Program_2018-2020.pdf

Toraman, C., Ata, H. A. ve Buğan, M. F. (2015). "Mevduat ve Katılım Bankalarının Karşılaştırmalı Performans Analizi", Cumhuriyet Üniversitesi İktisadi ve İdari Bilimler Fakültesi Dergisi, 16(2), 301-310.

Türkiye Katılım Bankaları Birliği [TKBB]. (2015). Türkiye katılım bankacılı̆̆ strateji belgesi 2015-2025. Erişim adresi: https://www.tkbb.org.tr/ Documents/Yonetmelikler/TKBB-Strateji-Belgesi.pdf

Usman, A. and Khan, M. K. (2012) "Evaluating the Financial Performance of Islamic and Conventional Banks of Pakistan: A Comparative Analysis", International Journal of Business and Social Science, 3(7), pp. 253-257.

Uzun, S. ve Kazan, H. (2016). "Çok Kriterli Karar Verme Yöntemlerinden AHP TOPSIS ve PROMETHEE Karşılaştırılması: Gemi İnşada Ana Makine 
Katılım Bankalarının Finansal Performans Analizi

Seçimi Uygulamas1", Journal of Transportation and Logistics, 1(1), ss. 99113.

Yanpar, A. (2014) İslami Finans, İlkeler, Araçlar ve Kurumlar, İstanbul. Scala Yayıncilik.

Yudistira, D. (2004) "Efficiency in Islamic Banking: An Empirical Analysis of Eighteen Banks", Islamic Economic Studies, 12(1), pp. 1-19.

https://www.bddk.org.tr/BultenAylik (Erişim tarihi: 03.03.2020)

http://www.ifk.com.tr/data/tasfiye-kurulu-karar-raporlari/a_2012_tasfiye_kurul u_faaliyet_raporu.pdf (Erişim tarihi: 30.03.2018)

https://www.tbb.org.tr/tr/bankacilik/banka-ve-sektor-bilgileri/4 (Erişim tarihi: 01.03.2020)

https://www.tkbb.org.tr/mukayeseli-tablolar (Erişim tarihi: 01.03.2020)

https://www.tkbb.org.tr/veri-seti (01.03.2020) 